\title{
INVESTOR SENTIMENT AND EARNINGS MANAGEMENT: DOES ANALYSTS' MONITORING MATTER?
}

\author{
KLÉBER F. MIRANDA ${ }^{1}$ \\ (iD) https://orcid.org/0000-0002-9164-6709 \\ MÁRCIO A. V. MACHADO \\ (iD) https://orcid.org/0000-0003-2635-5240 \\ LUCIANA A. F. MACEDO 3 \\ (iD) https://orcid.org/0000-0001-9861-9642
}

\begin{abstract}
To cite this paper: Miranda, K. F., Machado, M. A. V. , \& Macedo, L. A. F. (2018). Investor sentiment and earnings management: Does analysts' monitoring matter? Revista de Administração Mackenzie, 19(4). doi:10.1590/1678-6971/eRAMF180104
\end{abstract}

Submission: May 10, 2018. Acceptance: Jun. 7, 2018.

1 Universidade Federal Rural do Semi-Árido (Ufersa), Mossoró, RN, Brazil.

2 Universidade Federal da Paraíba (UFPB), João Pessoa, PB, Brazil.

3 União de Ensino Superior de Campina Grande (Unesc), Campina Grande, PB, Brazil.

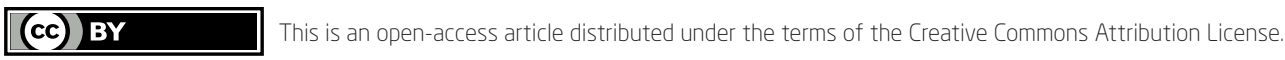

\footnotetext{
This paper may be copied, distributed, displayed, transmitted or adapted if provided, in a clear and explicit way, the name of the journal, the edition, the year and the pages on which the paper was originally published, but not suggesting that RAM endorses paper reuse. This licensing term should be made explicit in cases of reuse or distribution to third parties. It is not allowed the use for commercial purposes.

Este artigo pode ser copiado, distribuído, exibido, transmitido ou adaptado desde que citados, de forma clara e explícita, o nome da revista, a edição, o ano e as páginas nas quais o artigo foi publicado originalmente, mas sem sugerir que a RAM endosse a reutilização do artigo. Esse termo de licenciamento deve ser explicitado para os casos de reutilização ou distribuição para terceiros. Não é permitido o uso para fins comerciais.
} 


\section{ABSTRACT}

Purpose: Under the assumption that managers have incentives to practice earnings management in optimistic moments, this paper aims to analyze whether analysts' monitoring affects the relation between the discretionary accumulations (accruals) and investor sentiment in the Brazilian capital market.

Originality/value: The mediating role of analysts in the relation between investor sentiment and earnings management was not identified in the literature establishing an important gap to be investigated, given the relevance of the reported earnings for the decision-making process of market participants.

Design/methodology/approach: Fixed effects regressions (industry and quarter) were estimated from 2010 to 2016, using all data and the subsetting sample according to whether or not companies were monitored by analysts.

Findings: The results showed a reduction of earnings management after optimistic moments, which differs from the initial expectation and such behavior is attributed to the presence of analysts following companies. The results were robust to alternative proxies for earnings management and investor sentiment. Analysts have an influence on accounting earnings supporting the best disclosure, so inhibiting the practice of earnings management in optimistic moments. Therefore, although previous studies suggest that earnings management practices increase during optimistic moments, market participants may consider, even in such moments, a better earnings quality when firms are monitored by analysts.

\section{KEYWORDS}

Investor sentiment. Earnings management. Accruals. Analysts. Monitoring. 


\section{INTRODUCTION}

The fact that sentiment exerts an influence on investors (De Long, Shleifer, Summers, \& Waldmann, 1990) and that its effects on the capital market are difficult to be settled by arbitrators (Shleifer \& Vishny, 1997) makes way for managers and investors to make opportunistic choices. Investor sentiment is considered by Baker and Wurgler $(2006,2007)$ as a belief about cash flows and investment risks not justified by available data. It is either an optimistic or pessimistic return expectation compared to average earnings. (Brown \& Cliff, 2004). As a consequence, optimism in the capital market encourages, in addition to investors' decision-making, the action of managers, such as: dividend payment (Baker \& Wurgler, 2004), investment (Polk \& Sapienza, 2009), changes in capital structure (Baker \& Wurgler, 2002), and earnings management (Ali \& Gurun, 2009; Simpson, 2013).

In this context, decisions are made under the capacity to detect the moments in which optimism creates an excessive increase in prices compared to the fundamental value of the firm (Stein, 1996). In such circumstances, the excess value generated by market optimism allows investors and managers to use their skills opportunistically to achieve favorable results. This study focuses on the decisions deriving from discretionary practices when reporting accounting earnings. Evidence indicates that managers are more conservative after pessimistic periods and less conservative after optimistic sentiment periods, which implies the use of earnings management in optimistic moments (Simpson, 2013).

Earnings management is the deliberate use of accounting principles by managers focused on the desired level of reported earnings (Riahi-Belkaoui, 1999). The choices deriving from such discretionary process influence the output of the accounting system in a particular way, including tax returns and regulatory filings, in addition to financial statements (Fields, Lys, \& Vincent, 2001). Manipulation may be the opportunistic use of accrual-based discretionary accumulations, in which managers choose the best moment to acknowledge revenue and expenditure, thus affecting the profit in such period and leading the market to overpricing at that moment, to be reversed in the following years (Sloan, 1996). When we associate this context with the fact that investors are less alert to profit components (accruals and cash flow) in optimistic periods (Ali \& Gurun, 2009), it is reasonable that managers identify the timing for earnings management. 
This way, investor sentiment indices may indicate the opportune timing for earnings management, considering the positive relation between investor sentiment and discretionary accruals (Ali \& Gurun, 2009; Simpson, 2013). In optimistic periods, accounting information users must, therefore, be attentive to possible distortions of reported earnings. Consequently, timing is relevant for the analysis of earnings management, when evaluated from the perspective of optimistic market moments.

Still, the relation between investor sentiment and earnings management deserves attention, since evidence is still incipient, especially in studies on the Brazilian stock market. Some studies associate earnings management with the participation of market analysts-be it for the sake of inhibiting (Martinez, 2011) or fulfilling a forecast (Mota, Silva Filho, Oliveira, \& Paulo, 2017). Other studies focus on market noise, revealing a significant relation between earnings management and crisis-related variables (Silva, Weffort, Flores, \& Silva, 2014). Although such studies do not specifically deal with market sentiment indices, they focus on moments when analysts are optimistic or moments of crisis. Both situations can generate noise in the relation between firms' book and market value. It is worth mentioning that analyst coverage is negatively related to the magnitude of accruals (Martinez, 2011).

In this line of reasoning, some analyst-related evidences indicate that the number of analysts (Martinez, 2011) and earnings forecasts in IPO (Buchner, Mohamed, \& Saadouni, 2017) are factors that inhibit the practice of earnings management. Since the role of analysts, among other things, is to issue information on firm prices and indicate if stocks should be bought or sold, they take profit as an indispensable input-be it for discounted cash flows or price-to-earnings multiples (Demirakos, Strong, \& Walker, 2010; Sayed, 2017) — demanding that firms provide a better earnings report. However, the inhibiting factor created by analysts covering firms was not evidenced in such studies making it a gap to be investigated, since, as they favor other market participants, analysts may reverse the possibility of earnings management during optimistic periods.

This study focuses on the participation of market analysts as protagonist agents in mediating the relation between earnings management and investor sentiment. Simpson (2013) evaluated the role of analysts in such relation, however, that author evaluated if management aimed to meet the analysts' forecast, as in Mota et al. (2017) for the Brazilian market. Ali and Gurun (2009) evaluated some aspects of such relation without considering the role of analysts in their scope. Therefore, this study aims to analyze if 
analysts' monitoring affects the relation between discretionary accruals and investor sentiment in the Brazilian market.

This is a relevant theme because it contrasts the empirical view that demonstrates the positive association between investor sentiment and earnings management (Ali \& Gurun, 2009; Simpson, 2013) with another one, in which analysts are capable of inhibiting the practice of earnings management (Buchner et al., 2017; Martinez, 2011). This study evaluates whether analyst coverage has an impact in the relation between investor sentiment and earnings management, that is, if it works as a variable that mediates such relation. This study's findings indicate the influence of analysts on the reduction of the earnings management level after optimistic moments. The findings were robust to the alternative proxy of discretionary accruals and sentiment index. As a consequence, this study advances the literature, as it incorporates the participation of analysts to the improvement of reported earnings in moments susceptible to earnings management (optimism), suggesting an impact of investor sentiment on such an opportunistic behavior, as a function of analyst coverage.

This introductory section is followed by four additional sections. In the next section, we present the literature review, address the investor sentiment index and earnings management, and introduce the research hypotheses. Next, section 3 demonstrates the research methodology; section 4 presents the findings, and section 5 lays out the final comments. Finally, the last section lists the bibliographical references.

\section{EARNINGS MANAGEMENT AND INVESTOR SENTIMENT}

The analysis of earnings management consists of identifying the discretionary use of accruals by managers, and it can be done through several constructs (Dechow, Sloan, \& Sweeney, 1995; Jones, 1991; Kang \& Sivaramakrishnan, 1995; Pae, 2005). Total accruals, which originate in accrual accounting, are the difference between earnings and cash in one specific period. As a relevant measure, due to its use for an array of ends (paying shareholders, forecasting future cash flows, debt clauses), profit needs to be reliable. Despite making earnings more informative (Dechow, 1994), accruals become less reliable as opportunistic use increases. Therefore, managers must consider the moment and the firm's situation as they manage earnings since earnings are eventually priced by the market (Sloan, 1996). 
Several are the incentives for management: managers' pay (Ali \& Zhang, 2015; Dechow \& Sloan, 1991; Jensen \& Meckling, 1976), covenants (Dichev \& Skinner, 2002; Fields et al., 2001; Nardi \& Nakao, 2009; Sincerre, Sampaio, Famá, \& Santos, 2016), regulatory issues (Huang, Lao, \& McPhee, 2017; Rezende \& Nakao, 2012), market expectations and valuation (Abarbanell \& Lehavy, 2003; Almeida, Lopes, \& Corrar, 2011; Buchner et al., 2017; Martinez, 2011; Mota et al., 2017), which are the object of analysis for empirical researches.

This study uses the investor sentiment index and analyzes the practice of earnings management, based on discretionary accruals after moments of market optimism, given managers' ability to use such circumstances in an utilitarian way (Ali \& Zhang, 2015). Our work advances those of Ali and Gurun (2009) and Simpson (2013), because we evaluate the mediating role of market analysts in such relation. The results of Ali and Gurun (2009) focus primarily on small caps, for they are more likely to be followed by individual investors, who are acknowledged in the literature for their limited attention. These findings are corroborated by Simpson (2013), when that author reinforces the vulnerability of small caps to investor sentiment and the increase of both abnormal and total accruals in periods of high sentiment. In addition to influencing the level of earnings management (Buchner et al., 2017; Martinez, 2011), the inhibiting role of analysts may have an influence on the opportunistic behavior of managers in moments of market optimism.

Investor sentiment is an existing belief about future cash flows and investment risk explained by data that is not available (Baker \& Wurgler, 2007). Therefore, unfounded expectations of return reflect the setting in which investor sentiment is high (optimism). Lee, Shleifer, and Thaler (1991) highlight the existence of unpredictable fluctuations in the expectation of individual investors, whose returns are not secured by the fundamental value of assets, which denotes the influence of investor sentiment in the value of assets. This argument is corroborated by Brown and Cliff (2005), who report the effect of investor sentiment on assets, and identify that prices are set over their fundamental value when the market is optimistic.

Mispricing due to limits to arbitrage, observable through benchmarks, such as the book-to-market ratio, becomes a source of information to insiders, such as executives, who can use this information-superior to other market participants-and their incentive for using this advantage. This way, investor sentiment becomes observable, at the creation of a chain of events, whose exogenous shock may be observed in any part of the chain. Then, some measures may be taken to represent investor sentiment, 
such as surveys, retail investor trades, mutual fund flows, trading volume, among others (Baker \& Wurgler, 2007).

The relation between investor sentiment and discretionary earnings management is set by opportunism during periods of optimism. The mediation of analysts is a contribution to the literature, which mentions the inhibiting effect of the earnings management behavior, even during moments when the asset prices distance themselves from their fundamental value. In this context, as market participants evaluate firms followed by analysts, they will have greater confidence when using the firms' figures in their process of investment analysis or valuation.

\subsection{Proposing the research hypotheses}

The research hypotheses are presented in tune with the literature dedicated to underscoring the relation between investor sentiment and discretionary managerial behavior. This said, we will adopt the sentiment index in line with Baker and Wurgler (2006) and the earnings management measure built to isolate discretionary behavior from non-discretionary behavior. In this line of reasoning, in addition to setting this study's intent towards such relation, we incorporate the mediating role of market analysts, revealing two research hypotheses concerning the relation between investor sentiment and earnings management and the influence of analysts in such relation.

Considering motivations such as data from the capital market (investors' and analysts' information), contractual relations (management compensation or lending contracts) or regulations (Healy \& Wahlen, 1999), this paper presents two research hypotheses focused on the occurrence of earnings management due to market data, which makes it a capital market incentive for such practice. In addition, this study relates to other researches (Ayers, Jiang, \& Yeung, 2006; Burgstahler \& Dichev, 1997; Graham, Harvey, \& Rajgopal, 2005; Mota et al., 2017; Simpson, 2013), which focused on said incentive. Finally, we set out from the premise that earnings management is higher in high sentiment periods, leading to more conservative results in low sentiment periods. High sentiment periods accentuate economic incentives and stimulate a higher level of earnings management (Simpson, 2013).

Some empirical evidence reveals the use of high sentiment periods to present positive accruals, in order to reach earnings forecasts estimated by analysts (Bergman \& Roychowdhury, 2008; Hribar \& McInnis, 2012; Kent \& Routledge, 2017; Mota et al., 2017). Still, empirical evidence signals the 
intention of making earnings meet the analysts' estimates and not surpass them (Kent \& Routledge, 2017; Mota et al., 2017). In addition, due to a less optimistic concept of analysts about firms' earnings, managers are discouraged to increase accruals, even if they eventually do it. (Bergman \& Roychowdhury, 2008; Hribar \& McInnis, 2012).

This way, considering the difficulty of investors to clearly identify the components of earnings in high sentiment periods (Ali \& Gurun, 2009), and the managers' skill to identify such moments (Simpson, 2013), we set out from the premise that earnings management is greater in periods of high investor sentiment, due to the detachment of prices and firms' fundamental value in moments of market optimism, which culminates in the first hypothesis of this research:

$\mathrm{H}_{1}$ : Managers increase discretionary earnings management after periods of optimism.

On the other hand, it is necessary to evaluate if analysts' monitoring can interfere with the relation between investor sentiment and earnings management behavior. According to Martinez (2011), it is possible that the number of analysts can inhibit firms from having earnings management behavior, even after the evidences of Mota et al. (2017), who suggest the use of management to make earnings approach the values estimated by analysts, and those of da Silva et al. (2014), who relate the opportunistic use of earnings management behavior with moments of crisis. In addition to this, there are the evidence indicated by Buchner et al. (2017), that earnings management is lower among firms whose IPO forecasts a profit, which suggests that such opportunistic behavior is inhibited in the presence of analysts issuing estimates. In this context, we propose the second hypothesis of this research:

$\mathrm{H}_{2}$ : The relation between investor sentiment and earnings management is negative when firms are monitored by analysts.

\section{METHODOLOGY}

\subsection{Data and variables of interest}

The accounting data and the number of analysts were collected from the Thomson Reuters ${ }^{\circledR}$ (Eikon) platform, from which we selected all 
non-financial Brazilian firms traded at Brasil, Bolsa, Balcão (B3), from 2009 to 2016. The year of 2009 was included due to the use of lagged variables in the models, which allowed the effective analysis for the 2010-2016 period. This period is justified by the convergence of the Brazilian norms to the International Financial Reporting Standards (IFRS), since, before this period, some accounting elements were not present in the accounting statements, or their identification and measurement processes were different.

Initially, the quarterly data collected totaled 430 non-financial firms (14,752 observations). However, after excluding the 289 firms with null values for some variables analyzed in the research (11,249 observations), 2 firms with inconsistent data (132 observations), and 37 firms with available data for a period under 18 months (787 observations), the final sample comprised 102 firms (2,584 observations). Therefore, the panel data used was unbalanced. The number of quarters per firm was defined to use the greatest amount of data, with no harm to the fixed effect control per quarter. Of the 37 firms excluded on this criterion, 14 firms had data for less than 4 quarters, which implies the interference of firms with little data when controlling for fixed effects.

The variables of interest of this research are investor sentiment, earnings management and the number of analysts. The investor sentiment index used in this study is based on variables of the Brazilian market, following the methodology proposed by Baker and Wurgler (2007), also adopted in other researches about the Brazilian stock market (Xavier \& Machado, 2017; Yoshinaga \& Castro Junior, 2012). To analyze earnings management, the model of Pae (2005) was used, which is justified since it increases the predictive power of total accruals, as it includes operating cash flow variables in addition to reversing the accruals of the previous period. The number of analysts and the other control variables used in this research are shown in Figure 3.1.1. Next, we provide details on the procedures for creating the investor sentiment index and the earnings management proxy.

(Figure 3.1.1)

DESCRIPTION OF VARIABLES

\begin{tabular}{ll}
\hline Variable & Description \\
\hline Leverage & The firm's gross debt divided by lagged total assets \\
\hline ROA & Firm's operating profit divided by lagged total assets \\
\hline Size & Firm's total assets logarithm \\
\hline
\end{tabular}




\section{(Figure 3.1.1 (conclusion))}

\section{DESCRIPTION OF VARIABLES}

\begin{tabular}{ll}
\hline Variable & Description \\
\hline CFO & Firm's operating cash flow divided by lagged total assets \\
\hline MB & Firms' market equity divided by book equity \\
\hline Monit & Number of analysts \\
\hline
\end{tabular}

Source: Elaborated by the authors.

To calculate the investor sentiment index, we used four representative variables for the Brazilian capital market, namely: 1. the number of advancing issues to declining issues ratio (AD); 2. the number of IPOs (NIPO); 3. the ratio between the total volume of traded stocks and the sum of total volume of traded stocks and debt (NEI); and 4. the percentage of participation of funds as borrowers of shares (FUND). The first three variables (AD, NIPO, and NEI) were used by Xavier and Machado (2017), however, the fourth variable (FUND) was added to substitute turnover. On the last update to the index of Baker and Wurgler (2007), available at said authors' website, the turnover was suppressed from the index because it is influenced by high-frequency trades. The variables NIPO and FUND were collected from the B3 website and the variables AD and NEI were taken from the Economatica ${ }^{\circledR}$ data base. According to the methodology of Baker and Wurgler (2007), these variables were submitted to the principal component analysis (PCA) to obtain their common variation. The index, therefore, is the first principal component obtained through the PCA.

All four variables used in the PCA were lagged by 12 months, comprising 8 variables ( 4 of which contemporary and 4 lagged), used to extract the first principal component. After analyzing the correlation between each one of these 8 variables and the first principal component deriving from them, we chose the variables NEI, AD and FUND, all of which are contemporary, and NIPO lagged by 12 months because they have a greater correlation absolute value. To rid these variables of possible macroeconomic effects, all of them were orthogonalized through regression on macroeconomic variables (recession dummy of the Organisation for Economic Co-operation and Development [OECD], GDP growth in the last 12 months, employment growth, growth of expenditure on energy, growth of expenditure on durable and non-durable goods). The residuals generated at each regression were used as variables in a new PCA, whose principal component on orthogonalized data represents, in this study, the investor sentiment index (Sent). 
The index was found to be adjusted, for it explained $49 \%$ of the variance of its variables and an eigenvalue over 1 , as the Kaiser rule suggests. As we evaluated the index adjustment through parallel analysis, we observed the adequacy of the index, and the first principal component was found to be good for use. Equation 1 shows the estimated orthogonalized index:

$$
S E N T_{t}=0.10 N E I_{t}+0.56 N I P O_{t-12}+0.57 A D_{t}-0.60 F U N D_{t}
$$

Figure 3.1.2 is a superimposed graph of both scaled series of the sentiment index and Ibovespa index $\left(\mu=0 ; \sigma^{2}=1\right)$, from January/2005 to December/2016, showing a trend of optimism from 2010 to 2012, and pessimism from 2012 to 2017, whose behavior is later followed by the Ibovespa index.

\section{(Figure 3.1.2)}

\section{COMPARISON BETWEEN SENTIMENT INDEX AND THE IBOVESPA RETURN}

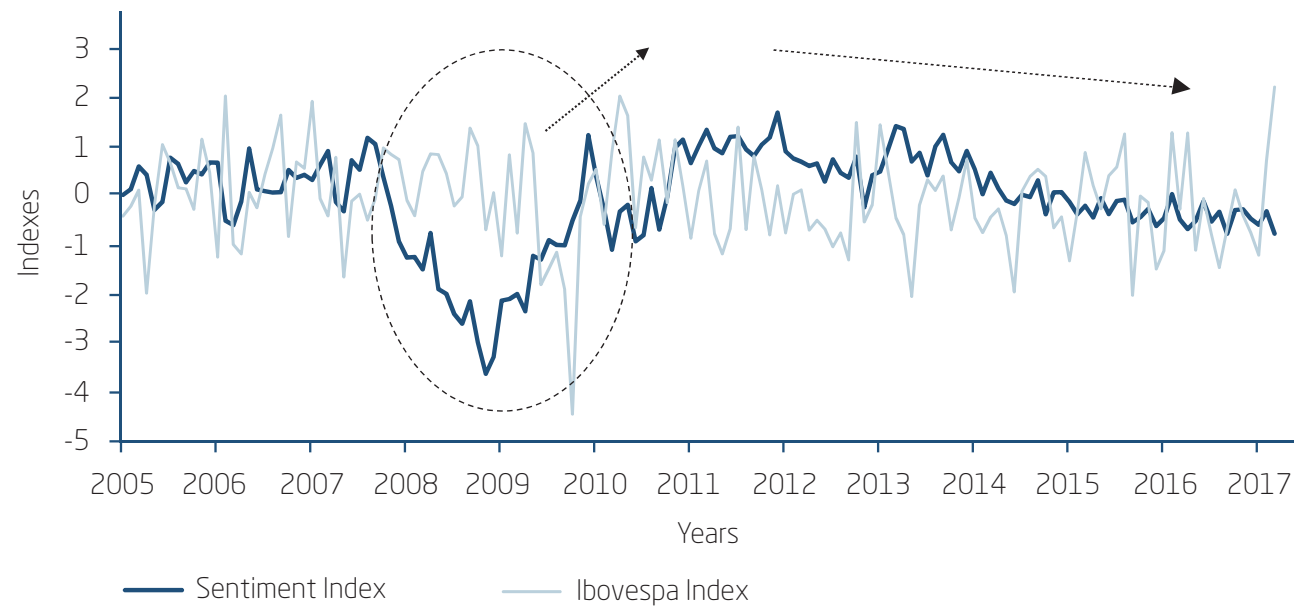

Source: Elaborated by the authors.

The earnings management proxy obtained on the residuals of the regression proposed by Pae (2005) is calculated as shown in Equation 2.

$$
\frac{T A_{t}}{A_{t-1}}=\alpha_{0} \frac{1}{A_{t-1}}+\alpha_{1} \frac{\Delta R E V_{t}}{A_{t-1}}+\alpha_{2} \frac{P P E_{t}}{A_{t-1}}+\lambda_{0} \frac{C F_{t}}{A_{t-1}}+\lambda_{1} \frac{C F_{t-1}}{A_{t-2}}+\lambda_{2} \frac{T A_{t-1}}{A_{t-2}}+\varepsilon_{t}
$$


Where,

$A_{t}$ : firms' total accruals in period $t$ divided by the total assets of period $t-1$, calculated by the difference between earnings before extraordinary items and the firm's operating cash flow (cash flow method);

$A_{t-1}:$ firm's total assets in period $t-1$;

$\triangle R E V_{t}$ : Variation of firms' net income in period $t$ divided by the total assets of period $t-1$;

$P P E_{t}:$ Firm's gross property, plant, and equipment in period $t$ divided by the total assets of period $t-1$;

$C F_{t}$ : Firms' operating cash flow in period $t$ divided by the total assets of period $t-1$;

$C F_{t-1}:$ Firms' operating cash flow in period $t$ - 1 divided by the total assets of period $t-2$;

$T A_{t-1}$ : Firms' total accruals in period $t-1$ divided by the total assets of period $t-2$;

$\varepsilon_{t}:$ Regression residual (proxy for discretionary accruals).

Given the specificity of each firm, the estimation of discretionary accruals would be more powerful if done per firm (Pae, 2005). However, Dechow, Hutton, Kim, and Sloan (2012) alert for power loss because some firms do not have enough data to allow conducting a regression process per firm, which leads to leaving the firm out of the sample. This way, to construct the management proxy we used cross-section regressions, separating the sample per industry and year. Eventually, the residual values obtained were transformed into absolute values, since managerial behavior may be incentivized to increase or reduce the difference between earnings and cash flow in one given period. This transformation led to evaluating the level of management regardless of the incentive, whether positive or negative.

\subsection{Data treatment and econometric model}

The variables of leverage, ROA, size, operating cash flow and market-to-book were lagged in one quarter, to analyze the relation with the discretionary accruals (earnings management). The sentiment index used was that for the previous month, therefore, this variable was lagged in one month. The other variables (number of analysts, industry dummies, and quarter dummies) are contemporary to the discretionary accruals. This way, to evaluate the propositions of each research hypothesis, we came to a single model shown in Equation 3. 


$$
\begin{aligned}
& \text { EM }_{i, t}=\alpha_{0}+\beta_{1} \text { Sent }_{t-1}+\beta_{2} \text { Leverage }_{i, t-1}+\beta_{3} \text { ROA }_{i, t-1}+\beta_{4} \text { Size }_{i, t-1}+\beta_{5} \text { CFO }_{i, t-1}+ \\
& \beta_{6} M_{i, t-1}+\beta_{7} \text { Monit }_{i, t}+\sum \lambda_{i}+\sum \delta_{t}+\varepsilon_{i, t}
\end{aligned}
$$

Where,

$E M_{i, t^{*}}$ Earnings management (Equation 2 residuals) of firm $i$ at time $t$;

Sent $_{t-1}$ : Investor sentiment index for the previous month;

Leverage $_{i, t-1}$ : Leverage of firm $i$ in the previous quarter;

$R O A_{i, t-1}:$ Return on assets of firm $i$ in the previous quarter;

Size $_{i, t-1}:$ Size proxy of firm $i$ in the previous quarter;

$\mathrm{CFO}_{i, t-1}:$ Operating cash flow of firm $i$ in the previous quarter;

$M B_{i, t-1}$ : Market-to-book ratio of firm $i$ in the previous quarter.

Monit $_{i, t}$ : Current number of analysts of firm $i$.

$\lambda_{i}$ : Industry dummies (fixed effects);

$\delta_{t}$ : Quarter dummies (fixed effects).

The coefficient of interest to analyze the research Hypothesis $1\left(\mathrm{H}_{1}\right)$, which managers increase the discretionary earnings management after periods of optimism, corresponds to investor sentiment $\left(\beta_{1}\right)$. This coefficient is expected to be positive, implying in the increase of earnings management behavior after periods of optimism. According to the assumptions made, after periods of optimism, managers would face a gap between prices and the fundamental value of assets, which favors earnings management. Then, when positive, coefficient $\beta_{1}$ indicates an increase in the level of discretionary accruals, due to the increase in the sentiment index.

The other coefficients serve to control the effects of investor sentiment on earnings management. The estimations were made on fixed effects controlling for industry and quarter. These controls mean the creation of a dummy variable for the industries and for each quarter. Figure 3.2.1 shows the variables laid out in the model and the expected sign for each relation with Earnings Management (EM). 


\section{(Figure 3.2.1)}

EXPECTED SIGNS FOR EACH INDEPENDENT VARIABLE IN RELATION TO EARNINGS MANAGEMENT

\begin{tabular}{lcl}
\multicolumn{1}{c}{ Variable } & Expected Sign & Source \\
\hline Sent $_{t-1}$ & + & (Ali \& Gurun, 2009; Simpson, 2013) \\
\hline Leverage $_{i, t-1}$ & + & (Dechow, Sloan, \& Sweeney, 1996) \\
\hline ROA $_{i,-1}$ & - & (Gu, Lee, \& Rosett, 2005) \\
\hline Size $_{i,-1}$ & - & (Dechow, Ge, \& Schrand, 2010) \\
\hline CFO $_{i,-1}$ & + & (Dechow et al., 1996; Gu et al., 2005) \\
\hline MB $_{i, t-1}$ & + & (Almeida et al., 2011) \\
\hline Monit $_{i, t}$ & - & (Buchner et al., 2017; Martinez, 2011) \\
\hline
\end{tabular}

The analysis of the research Hypothesis $2\left(\mathrm{H}_{2}\right)$, for which the relation between investor sentiment and earnings management is negative when firms are more monitored by analysts, followed the same parameters of the research Hypothesis $1\left(\mathrm{H}_{1}\right)$. However, in the model proposed in Equation 3, the variable regarding the number of analysts (Monit) was withdrawn from the analysis. The number of analysts, initially used to analyze all the sample, eventually served to segregate the sample into two groups. Research Hypothesis $2\left(\mathrm{H}_{2}\right)$ suggests reversing the sign of the relation between investor sentiment and earnings management, considering analysts' monitoring. This way, the sample was divided into a group comprising firms monitored by analysts ("monitored") and another group comprising firms not followed by analysts ("unmonitored").

We expect a negative value for the investor sentiment coefficient $\left(\beta_{1}\right)$ for the "monitored" group and a positive value for the "unmonitored" group. The "monitored" group comprises firms followed by analysts, therefore, after moments of optimism, a negative relation between investor sentiment and earnings management is expected, since opportunistic behavior is inhibited by the presence of analysts. Therefore, in this perspective, the coefficient $\beta_{1}$ must be negative when the analyzed firms are followed by analysts. On the other hand, when firms are not followed by analysts ("unmonitored"), the earnings management behavior is eventually not inhibited by such agents, which changes the effect of the investor sentiment over the level of firms' accruals, making coefficient $\beta_{1}$ a positive one. 


\section{RESULTS ANALYSIS AND DISCUSSION}

The values shown in Figure 4.1 cover the descriptive statistics selected for analyzing all variables, both dependent and independent ones, of the model shown in Equation 3. The dependent variable (EM) is expressed in absolute values. Therefore, since there is no negative value, the minimum value of EM is zero, which represents the equality between the estimated value for the total accruals and its actual value. The maximum value of EM (0.131) means that the greatest difference between the value of earnings and cash flow, related to opportunistic management, is, on average, $13 \%$ of the total assets for the previous period.

\section{(Figure 4.1)}

DESCRIPTIVE STATISTICS

\begin{tabular}{lccccccc}
\hline \multicolumn{1}{c}{ Variable } & Average & Deviation & Minimum & Q.25 & Median & Q.75 & Maximum \\
\hline EM $_{i, t}$ & 0.011 & 0.014 & 0.000 & 0.003 & 0.007 & 0.014 & 0.131 \\
\hline Sent $_{t-1}$ & 0.517 & 0.747 & -0.637 & -0.172 & 0.194 & 1.338 & 1.791 \\
\hline Leverage $_{i,-1}$ & 0.326 & 0.166 & 0.000 & 0.210 & 0.322 & 0.428 & 1.081 \\
\hline ROA $_{i, t-1}$ & 0.021 & 0.030 & -0.164 & 0.009 & 0.018 & 0.032 & 0.902 \\
\hline Size $_{i,-1}$ & 15.475 & 1.321 & 11.792 & 14.581 & 15.362 & 16.388 & 18.981 \\
\hline CFO $_{i, t-1}$ & 0.018 & 0.037 & -0.570 & 0.001 & 0.018 & 0.036 & 0.314 \\
\hline MB $_{i,-1}$ & 1.895 & 1.986 & -45.252 & 0.765 & 1.372 & 2.410 & 12.477 \\
\hline Monit $_{i, t}$ & 7.068 & 5.049 & 0.000 & 2.000 & 7.000 & 11.000 & 18.000 \\
\hline
\end{tabular}

Note: $\mathrm{EM}_{i, t}$ is the earnings management proxy, measured on the residuals of the model of Pae (2005). Sent $t_{t-1}$ is the investor sentiment index of the previous month, measured as explained in Section 0. Leverage ${ }_{i t-1-1}$ is the leverage of the previous quarter, calculated by the gross debt divided by lagged total assets. ROA $\mathrm{A}_{i,-\mathrm{I}}$ is the return on assets in the previous quarter, calculated by the operating profit divided by lagged total assets. Size $_{i t-1}$ is the firm size proxy, calculated by the natural logarithm of the total assets of the previous quarter. $\mathrm{CFO}_{i, t-1}$ is the operating cash flow of the previous quarter, calculated by the operating cash flow divided by lagged total assets. MB $_{i, t-1}$ is the market-tobook ratio of the previous quarter, calculated by the ratio of market equity divided by book equity. Monit is the number or analysts following a firm in the current period. Q.25 is the $25 \%$ quantile. Q.75 is the $75 \%$ quantile.

Source: Elaborated by the authors.

Regarding the other (independent) variables, the standard deviation is lower in relation to the average for the variables of leverage, size and number of analysts (Monit), which suggests less data dispersion. The variable MB 
has greater extreme values in relation to the average (1.895), at a maximum of 12.477 and minimum of 45.252 , showing that extreme values for firm devaluation are higher than its valuation. The ROA and the CFO follow the same behavior as that of $\mathrm{MB}$, however, with lower extreme values. Nevertheless, the MB, ROA, and CFO are positive $(0.765,0.009$ and 0.001 , respectively) in the first $25 \%$ of the sample (Q.25).

As to the number of analysts (Monit), it is noteworthy that firms are followed by 7 analysts on average, ranging from zero in unmonitored firms to 18 in firms with the greatest monitoring. The most optimistic firms had an index of 1.791 while the most pessimistic firms scored 0.637. On average, the index is positive, which shows optimism from 2010 to 2017. However, the standard deviation above the average reveals a volatile sentiment in this period.

\subsection{Analysis of the relation between investor sentiment and earnings management}

To analyze the research Hypotheses $\left(\mathrm{H}_{1}\right.$ and $\left.\mathrm{H}_{2}\right)$, Figure 4.1 .1 has three columns deriving from the estimation of fixed effects controlling for industry and quarter. The first column (All sample) corresponds to the outcomes of the estimation of the model proposed in Equation 3, using all the sample. This column uses the information necessary to evaluate the research Hypothesis $1\left(\mathrm{H}_{1}\right)$. The other columns refer to the estimation segregated by monitored firms and unmonitored firms. This segregation led to the evaluation of research Hypothesis $2\left(\mathrm{H}_{2}\right)$.

\section{(Figure 4.1.1)}

OUTCOMES OF THE RELATION BETWEEN INVESTOR SENTIMENT AND EARNINGS MANAGEMENT

\begin{tabular}{|c|c|c|c|}
\hline Variables & All sample & Monitored & Unmonitored \\
\hline Constant & $\begin{array}{c}0.020 \\
(3.365)\end{array}$ & $\begin{array}{c}0.033 \\
(5.236)\end{array}$ & $\begin{array}{c}0.025 \\
(2.114)\end{array}$ \\
\hline Sent $_{t-1}$ & $\begin{array}{c}-0.001 \\
(-2.853)\end{array}$ & $\begin{array}{c}-0.001 \\
(-3.821)\end{array}$ & $\begin{array}{c}0.002 \\
(1.677)\end{array}$ \\
\hline
\end{tabular}




\section{(Figure 4.1.1 (conclusion))}

OUTCOMES OF THE RELATION BETWEEN INVESTOR SENTIMENT
AND EARNINGS MANAGEMENT

\begin{tabular}{lccc}
\multicolumn{1}{c}{ Variables } & All sample & Monitored & Unmonitored \\
\hline Leverage $_{i,-1}$ & -0.002 & -0.003 & 0.002 \\
& $(-0.735)$ & $(-1.403)$ & $(0.306)$ \\
\hline ROA $_{i, t-1}$ & -0.032 & -0.029 & -0.089 \\
& $(-2.171)$ & $(-2.037)$ & $(-2.176)$ \\
\hline Size $_{i,-1}$ & $<0.000$ & -0.001 & -0.001 \\
& $(-0.706)$ & $(-2.874)$ & $(-0.819)$ \\
\hline CFO $_{i, t-1}$ & -0.018 & -0.018 & -0.015 \\
& $(-2.061)$ & $(-2.086)$ & $(-0.625)$ \\
\hline MB $_{i,-1}$ & $<0.001$ & $<0.001$ & $<0.000$ \\
& $(1.235)$ & $(0.549)$ & $(-0.189)$ \\
\hline Monit $_{i, t}$ & $<0.000$ & & \\
\hline Industry Dummy & $(-4.790)$ & & Yes \\
\hline Quarter Dummy & Yes & Yes & Yes \\
\hline $\mathrm{R}^{2}$ (Adjusted $\mathrm{R}^{2}$ ) & Yes & Yes & 372 \\
\hline Number of observations & $0.081(0.074)$ & $0.069(0.062)$ & $0.087(0.049)$ \\
\hline
\end{tabular}

Note: The dependent variable $E M_{i, t}$ is the earnings management proxy, measured on the residuals of the model of Pae (2005). Sent $t_{t-1}$ is the investor sentiment index of the previous month, measured as explained in Section 0. Leverage $_{i, t-1}$ is the leverage of the previous quarter, calculated by the gross debt divided by lagged total assets. $\mathrm{ROA}_{i,-1}$ is the return on assets in the previous quarter, calculated by the operating profit divided by lagged total assets. Size $_{i, t-1}$ is the proxy for firm size, calculated by the natural logarithm of the total assets of the previous quarter. $\mathrm{CFO}_{i, t-1}$ is the operating cash flow of the previous quarter, calculated by the operating cash flow divided by lagged total assets. $\mathrm{MB}_{i, t-\mathrm{I}}$ is the market-to-book ratio of the previous quarter, calculated by the ratio of market equity divided by book equity. Monit ${ }_{i, t}$ is the number or analysts of the firm in the current period. . $\sum \lambda_{j}$ Dummies for industry (fixed effects). $\sum \delta_{t}$ Dummies for quarters (fixed effects). The normality hypothesis is relaxed based on the central limit theorem (Greene, 2012). The estimation errors demonstrate the absence of homoskedasticity and the presence of autocorrelation, therefore, below each coefficient, in parentheses, are the respective $t$-statistics adjusted to the Newey-West standard errors.

Source: Elaborated by the authors.

The results shown in the column "All Sample" of Figure 4.1.1 suggest there is no relation between leverage, market-to-book ratio (MB) or firm size and earnings management, given the lack of statistical significance of 
their coefficients ( $\mathrm{t}$-statistics of $0.735,1.235$ and 0.706 , respectively). The average leverage being $32 \%$ of the total assets (Figure 4.1 ) can also indicate a low incentive to earnings management in relation to the total debt, besides the fact that the stimulus to debt management may take place in different periods according to the covenant restraints (DeAngelo, DeAngelo, \& Skinner, 1994). The market-to-book ratio is considered a ratio relative to a factor of market optimism, because it indicates high expectations for firms' earnings and cash flow (Almeida et al., 2011). Its effect may have been absorbed by the investor sentiment index (Sent). Likewise, the size effect may have been captured by the number of analysts (Monit), justified by the fact that bigger firms are followed by a greater number of analysts, given the higher number of public information to be produced and higher costs (Hope, 2003).

The other variables in the column "All Sample" (Figure 4.1.1) are significant, which indicates the reduction in the level of earnings management when profitability (ROA) or operating cash flow (CFO) increases. The number of analysts (Monit) also had a negative and significant coefficient (t-statistics 4.790), which corroborates Martinez (2011), as to the analysts inhibiting the earnings management behavior. However, this fact itself is not enough to relate the influence of monitoring with the relation between investor sentiment and earnings management, although the investor sentiment coefficient (Sent) has been negative (0.001), only to reject the research Hypothesis $1\left(\mathrm{H}_{1}\right)$.

There is an indication of the influence of firms' monitoring on the opportunistic behavior of earnings management in optimistic moments, preventing the increase of such practice after periods of high investor sentiment, as proposed by Simpson (2013). However, some analyzed firms are not followed by analysts and may have a different behavior from the group of firms, even those followed by analysts. The sign of the investor sentiment coefficient $\left(\beta_{1}\right)$ different from that proposed by the research Hypothesis $1\left(\mathrm{H}_{1}\right)$ may, therefore, be influenced only by the firms followed by analysts.

The influence of analysts' monitoring on the relation between the earnings management behavior and investor sentiment is evaluated in the proposition of research Hypothesis $2\left(\mathrm{H}_{2}\right)$, for which there is a change of effect (divergent signs) when the analysis is conducted, separately, between the firms that are followed by analysts and those that are not. The outcomes of such analysis are also shown in Figure 4.1.1. 
In the column "Monitored", we see a negative sign of the coefficient of the variable investor sentiment (coef. 0.001) and a divergent sign (coef. 0.002) in the column "Unmonitored", and both are significant at $1 \%$ and $10 \%$, respectively. The results suggest the use of optimistic moments to manage earnings when firms are not followed by analysts. Therefore, in association with the findings of Buchner et al. (2017), research Hypothesis $2\left(\mathrm{H}_{2}\right)$ cannot be rejected. As a consequence, we suggest reversing the earnings management behavior of firms followed by analysts during moments of optimism, which leads to a great credibility of the earnings reported by the public firms, the more they are followed by analysts.

The analyzed results did not converge with the notion of a greater earnings management after moments of market optimism, however, they show the influence of analysts' monitoring in such relation. In view of this, the first research Hypothesis $\left(\mathrm{H}_{1}\right)$ was rejected; however, since research Hypothesis $2\left(\mathrm{H}_{2}\right)$ was not rejected, it led to an important role played by analysts, namely, inhibiting the earnings management behavior even after moments of optimism.

\subsection{Robustness tests}

To evaluate the robustness of the results obtained so far, we conducted additional analyses, shown in Figure 4.2.1, to analyze the sensitivity of the results to the proxies used for earnings management and investor sentiment, besides comparing the results for companies followed by few and many analysts defined in the samples of the extreme quartiles based on the number of analysts. The alternative proxy for earnings management was obtained by the estimation of discretionary accruals through the model of Dechow (2012), which is different from the model evaluated first (Pae, 2005), in that the new model incorporates the cash flow effects. As to the alternative proxy for investor sentiment, we used the ICC of Fecomércio-São Paulo State Trade Federation (Federação do Comércio do Estado de São Paulo)—because due to the methodological proximity it is the closest index to that of the University of Michigan, (Xavier \& Machado, 2017). 


\section{(Figure 4.2.1)}

\section{ROBUSTNESS TESTS FOR THE RELATION BETWEEN INVESTOR SENTIMENT AND EARNINGS MANAGEMENT}

\begin{tabular}{|c|c|c|c|c|c|c|c|c|}
\hline \multicolumn{9}{|c|}{$\begin{array}{l}\text { EM }_{i, t}=\alpha_{0}+\beta_{1} \text { Sent }_{t-1}+\beta_{2} \text { Leverage }_{i, t-1}+\beta_{3} \text { ROA }_{i, t-1}+\beta_{4} \text { Size }_{i, t-1}+\beta_{5} \mathrm{CFO}_{i, t-1}+\beta_{6} M_{i, t-1}+ \\
\beta_{7} \text { Monit }_{i, t}+\sum \lambda_{i}+\sum \delta_{t}+\varepsilon_{i, t}\end{array}$} \\
\hline \multirow{2}{*}{ Variables } & \multicolumn{3}{|c|}{ EM = Dechow et al. (2012) } & \multicolumn{3}{|c|}{ Sent $=$ ICC } & \multicolumn{2}{|c|}{ Quartiles } \\
\hline & $(1)$ & (2) & (3) & (1) & (2) & (3) & $<0.25$ & $>0.75$ \\
\hline Constant & $\begin{array}{c}0.046 \\
(5.142)\end{array}$ & $\begin{array}{c}0.066 \\
(6.057)\end{array}$ & $\begin{array}{c}0.036 \\
(2.014)\end{array}$ & $\begin{array}{c}0.021 \\
(3.402)\end{array}$ & $\begin{array}{c}0.035 \\
(5.101)\end{array}$ & $\begin{array}{c}0.015 \\
(1.174)\end{array}$ & $\begin{array}{c}0.013 \\
(1.425)\end{array}$ & $\begin{array}{c}0.045 \\
(3.552)\end{array}$ \\
\hline Sent $_{t-1}$ & $\begin{array}{c}-0.001 \\
(-1.582)\end{array}$ & $\begin{array}{c}-0.001 \\
(-1.675)\end{array}$ & $\begin{array}{l}-0.001 \\
(-0.338)\end{array}$ & $\begin{array}{c}<0.000 \\
(-1.347)\end{array}$ & $\begin{array}{c}<0.000 \\
(-2.003)\end{array}$ & $\begin{array}{l}<0.001 \\
(2.645)\end{array}$ & $\begin{array}{c}<0.000 \\
(-0.297)\end{array}$ & $\begin{array}{l}-0.002 \\
(-3.151)\end{array}$ \\
\hline Leverage $_{i, t-1}$ & $\begin{array}{c}0.007 \\
(1.997)\end{array}$ & $\begin{array}{c}0.004 \\
(0.996)\end{array}$ & $\begin{array}{c}0.018 \\
(1.857)\end{array}$ & $\begin{array}{c}-0.002 \\
(-0.753)\end{array}$ & $\begin{array}{c}-0.004 \\
(-1.428)\end{array}$ & $\begin{array}{c}0.002 \\
(0.311)\end{array}$ & $\begin{array}{c}0.002 \\
(0.333)\end{array}$ & $\begin{array}{c}0.000 \\
(0.065)\end{array}$ \\
\hline $\mathrm{ROA}_{i, t-1}$ & $\begin{array}{l}-0.016 \\
(-0.920)\end{array}$ & $\begin{array}{c}-0.023 \\
(-1.187)\end{array}$ & $\begin{array}{l}-0.020 \\
(-0.322)\end{array}$ & $\begin{array}{c}-0.032 \\
(-2.167)\end{array}$ & $\begin{array}{c}-0.029 \\
(-2.008)\end{array}$ & $\begin{array}{c}-0.092 \\
(-2.261)\end{array}$ & $\begin{array}{c}-0.043 \\
(-1.067)\end{array}$ & $\begin{array}{c}-0.004 \\
(-0.168)\end{array}$ \\
\hline Size $_{i, t-1}$ & $\begin{array}{l}-0.002 \\
(-3.007)\end{array}$ & $\begin{array}{c}-0.003 \\
(-4.532)\end{array}$ & $\begin{array}{l}-0.002 \\
(-1.295)\end{array}$ & $\begin{array}{c}<0.000 \\
(-0.654)\end{array}$ & $\begin{array}{c}-0.001 \\
(-2.807)\end{array}$ & $\begin{array}{c}-0.001 \\
(-0.627)\end{array}$ & $\begin{array}{l}<0.001 \\
(0.248)\end{array}$ & $\begin{array}{l}-0.002 \\
(-2.262)\end{array}$ \\
\hline $\mathrm{CFO}_{i, t-1}$ & $\begin{array}{l}-0.005 \\
(-0.242)\end{array}$ & $\begin{array}{l}-0.006 \\
(-0.271)\end{array}$ & $\begin{array}{c}0.004 \\
(0.118)\end{array}$ & $\begin{array}{c}-0.017 \\
(-2.013)\end{array}$ & $\begin{array}{c}-0.018 \\
(-2.093)\end{array}$ & $\begin{array}{c}-0.019 \\
(-0.802)\end{array}$ & $\begin{array}{c}-0.026 \\
(-1.632)\end{array}$ & $\begin{array}{c}0.012 \\
(1.030)\end{array}$ \\
\hline $\mathrm{MB}_{i,-1}$ & $\begin{array}{c}0.001 \\
(2.738)\end{array}$ & $\begin{array}{l}<0.001 \\
(0.909)\end{array}$ & $\begin{array}{c}0.001 \\
(1.015)\end{array}$ & $\begin{array}{l}<0.001 \\
(1.204)\end{array}$ & $\begin{array}{l}<0.001 \\
(0.511)\end{array}$ & $\begin{array}{l}<0.000 \\
(-0.431)\end{array}$ & $\begin{array}{c}<0.000 \\
(-0.393)\end{array}$ & $\begin{array}{l}<0.001 \\
(0.090)\end{array}$ \\
\hline Monit $_{i, t}$ & $\begin{array}{l}<0.000 \\
(-2.566)\end{array}$ & & & $\begin{array}{c}<0.000 \\
(-4.823)\end{array}$ & & & $\begin{array}{c}0.001 \\
(0.966)\end{array}$ & $\begin{array}{c}-0.001 \\
(-2.217)\end{array}$ \\
\hline Industry Dummy & Yes & Yes & Yes & Yes & Yes & Yes & Yes & Yes \\
\hline Quarter Dummy & Yes & Yes & Yes & Yes & Yes & Yes & Yes & Yes \\
\hline$R^{2}$ & 0.054 & 0.056 & 0.097 & 0.079 & 0.066 & 0.092 & 0.047 & 0.109 \\
\hline Adjusted $R^{2}$ & 0.048 & 0.049 & 0.059 & 0.072 & 0.059 & 0.054 & 0.021 & 0.084 \\
\hline $\begin{array}{l}\text { Number of } \\
\text { observations }\end{array}$ & 2.584 & 2.212 & 372 & 2.584 & 2.212 & 372 & 664 & 627 \\
\hline
\end{tabular}

Note: (1) All sample, (2) Monitored, and (3) Unmonitored. The dependent variable EM ${ }_{i, t}$ is the earnings management proxy, measured on the residuals of the model of Pae (2005). Sent ${ }_{t-1}$ is the investor sentiment index of the previous month, measured as explained in Section 0. Leverage $i_{i t-1}$ is the leverage of the previous quarter, calculated by the gross debt divided by lagged total assets. $\mathrm{ROA}_{i,-I}$ is the return on assets in the previous quarter, calculated by the operating profit divided by lagged total assets. Size ${ }_{i,-1}$ is the proxy for firm size, calculated by the natural logarithm of the total assets of the previous quarter. CFO ${ }_{i t-1}$ is the operating cash flow of the previous quarter, calculated by the operating cash flow divided by lagged total assets. $\mathrm{MB}_{\text {it-s }}$ is the market-to-book ratio of the previous quarter, calculated by the ratio of market equity divided by book equity. Monit $t_{i t}$ is the number or analysts of the firm in the current period. . $\sum \lambda_{j}$ Dummies for industry (fixed effects). $\sum \delta_{t}$ Dummies for quarters (fixed effects). 
The normality hypothesis is relaxed based on the central limit theorem (Greene, 2012). The estimation errors demonstrate the absence of homoskedasticity and the presence of autocorrelation, therefore, below each coefficient, in parentheses, are the respective t-statistics adjusted to the Newey-West standard errors.

\section{Source: Elaborated by the authors.}

Figure 4.2.1 lays out all the results for the proposed robustness tests, subdivided into 8 result columns, the first 3 of which are for the estimations conducted with the dependent alternative variable of earnings management, the next 3 columns are for estimations conducted with the independent alternative variable for investor sentiment, and the last 2 columns are dedicated to the analysis based on the extreme quartiles of the samples based on the number of analysts.

The results were found to be robust to the new alternative proxies evaluated in consonance with the results previously obtained. Both the robustness tests of Figure 4.2.1 show a negative relation between investor sentiment and earnings management when the sample comprises only firms followed by analysts, which suggests that such opportunistic behavior is inhibited after moments of optimism. The relation becomes positive, as we evaluate the ICC as a proxy for sentiment in the sample comprising firms not followed by analysts. The analysis based on the number of analysts had a negative sign in the samples with the least and most analysts. However, it was significant only in the sample with the most analysts, which reinforces the negative relation between investor sentiment and earnings management in the most monitored firms. Therefore, the results for the robustness tests restate the notion that analysts contribute to making the relation between investor sentiment and earnings management a negative one.

\section{FINAL CONSIDERATIONS}

Assuming the possibility that managers behave opportunistically during periods of market optimism through earnings management, we analyzed the inhibiting role of market analysts over such behavior during periods of high investor sentiment. The objective of analyzing if analysts' monitoring affects the relation between discretionary accumulations (accruals) and investor sentiment in the Brazilian stock market was met, revealing a negative effect of investor sentiment on the accruals level, which contradicts the first hypothesis of this research. However, as we controlled this effect on analysts following firms, we found that results were kept for firms followed by analysts. Even though the results—robust to alternative proxies of earnings 
management and investor sentiment—do not show a greater level of earnings management after periods of optimism, they are in line with the belief of analysts' influence towards this negative relation.

The initial results contradict the expectation proposed by our research Hypothesis $1\left(\mathrm{H}_{1}\right)$, because we expected a positive association between investor sentiment and the level of accruals, suggesting the use of optimistic periods to manage results. The negative relation found was attributed to the possibility that analysts inhibit the earnings management behavior, which is justified by the negative effect caused by the number of analysts on the accruals level. Considering this aspect alone, we concluded that the level of accruals is reduced after periods of market optimism.

When considering whether or not firms are followed by analysts, we found a panorama that converges with the hypothesis that analysts inhibit earnings management behavior. The research Hypothesis $2\left(\mathrm{H}_{2}\right)$ aimed to evaluate the influence of analysts on the relation between investor sentiment and earnings management. In such analysis, we found divergent signs between the classifications based on the presence of analysts, which was positive for the sample not followed by analysts and negative for the sample followed by analysts. This fact eventually represented a possible explanation for the reduction of the level of accruals after optimistic periods, since the presence of analysts was found to influence the relation between investor sentiment and earnings management. Based on this study's findings, it was possible to propose an active role of analysts in the Brazilian stock market to inhibit managers' opportunistic behavior, especially earnings management.

We underscore the convergence of the control variables Leverage, ROA, and Size to the expected signs when their coefficients were significant in the principal analysis and the robustness analysis. The sign of the variable Operating Cash Flow was different from what we expected. Therefore, it is possible to identify a set of accounting variables, in addition to investor sentiment, which implies earnings management. The practical implication of this study's results, limited to the researched sample, is in the perception of market agents over the reported earnings by firms in periods of optimism when they are monitored by analysts. We found that analysts' monitoring is an ally in the information process, especially because it inhibits the earnings management behavior in moments of optimism because such period is a chance for managers' opportunistic behavior.

Apart from the number of analysts, other agents, such as institutional investors, can also contribute to reducing the opportunistic behavior in periods of high sentiment. Researches that can identify information about 
such agents may evaluate their role in mitigating the earnings management behavior in periods of optimism. In addition, new studies can evaluate alternative proxies to represent investor sentiment in the Brazilian stock market.

\section{SENTIMENTO DO INVESTIDOR E GERENCIAMENTO DE RESULTADOS: $O$ MONITORAMENTO DOS ANALISTAS IMPORTA?}

\section{$\int$ RESUMO}

Objetivo: Sob o pressuposto de haver maior incentivo para os gestores gerenciarem resultados em momentos otimistas, esta pesquisa analisa se o monitoramento realizado pelos analistas afeta a relação entre as acumulações discricionárias (accruals) e o sentimento do investidor no mercado acionário brasileiro.

Originalidade/relevância: O papel moderador dos analistas na relação entre sentimento do investidor e gerenciamento de resultados não foi identificado na literatura, constituindo uma importante lacuna a ser pesquisada, dada a importância do lucro reportado para o processo decisório dos participantes do mercado.

Principais aspectos metodológicos: Foram estimadas regressões de efeitos fixos (setor e trimestre) com dados trimestrais de 2010 a 2016, utilizando todos os dados e segregando a amostra de acordo com o acompanhamento ou não das empresas por analistas.

Síntese dos principais resultados: Os resultados indicaram uma redução no gerenciamento de resultados após períodos de otimismo, distanciando-se da expectativa inicial, sendo possível atribuir esse comportamento à presença de analistas nas empresas. Os resultados foram robustos a proxies alternativas para gerenciamento de resultados e sentimento do investidor. Os analistas exercem influência sobre a formação do lucro contábil, favorecendo a sua melhor evidenciação, quando inibem a prática de gerenciamento de resultados em momentos otimistas. Portanto, embora pesquisas anteriores demonstrem que a prática de gerenciamento de resultados aumenta durante momentos otimistas, os participantes 
do mercado podem considerar, mesmo nesses momentos, uma melhor qualidade do lucro quando as empresas forem monitoradas por analistas.

\section{$\int$ PALAVRAS-CHAVE}

Sentimento do investidor. Gerenciamento de resultados. Accruals. Analistas. Monitoramento.

\section{$\int$ REFERENCES}

Abarbanell, J. S., \& Lehavy, R. (2003). Can stock recommendations predict earnings management and analysts' earnings forecast errors? Journal of Accounting Research, 41 (1), 1-31. doi:10.1111/1475-679X.00093

Ali, A., \& Gurun, U. G. (2009). Investor sentiment, accruals anomaly, and accruals management. Journal of Accounting, Auditing \& Finance, 24(3), 415431. doi:10.1177/0148558X0902400305

Ali, A., \& Zhang, W. (2015). CEO tenure and earnings management. Journal of Accounting andEconomics, 59(1),60-79. doi:10.1016/j.jacceco.2014.11.004 Almeida, J. E. F. de, Lopes, A. B., \& Corrar, L. J. (2011). Gerenciamento de resultados para sustentar a expectativa do mercado de capitais: Impactos no índice market-to-book. Advances in Scientific and Applied Accounting, 4(1), 44-62. Retrieved from http://www.spell.org.br/documentos/download/14508

Ayers, B. C., Jiang, J. (Xuefeng), \& Yeung, P. E. (2006). Discretionary accruals and earnings management: An analysis of pseudo earnings targets. The Accounting Review, 81 (3), 617-652. doi:10.2308/accr.2006.81.3.617

Baker, M., \& Wurgler, J. (2002). Market timing and capital structure. The Journal of Finance, 57, 1-32. doi:10.1111/1540-6261.00414

Baker, M., \& Wurgler, J. (2004). A catering theory of dividends. The Journal of Finance, 59(3), 1125-1165. doi:10.1111/j.1540-6261.2004.00658.x

Baker, M., \& Wurgler, J. (2006). Investor sentiment and the cross-section of stock returns. The Journal of Finance, 61 (4), 1645-1680. doi:10.1111/j.15406261.2006.00885.x

Baker, M., \& Wurgler, J. (2007). Investor sentiment in the stock market. Journal of Economic Perspectives, 21 (2), 129-151. doi:10.1257/jep.21.2.129 
Bergman, N. K., \& Roychowdhury, S. (2008). Investor sentiment and corporate disclosure. Journal of Accounting Research, 46(5), 1057-1083. doi:10.1111/j.1475-679X.2008.00305.x

Brown, G. W., \& Cliff, M. T. (2004). Investor sentiment and the near-term stock market. Journal of Empirical Finance, 11(1), 1-27. doi:10.1016/j. jempfin.2002.12.001

Brown, G. W., \& Cliff, M. T. (2005). Investor sentiment and asset valuation. The Journal of Business, 78(2), 405-440. doi:10.1086/427633

Buchner, A., Mohamed, A., \& Saadouni, B. (2017). The association between earnings forecast in IPOs prospectuses and earnings management: An empirical analysis. Journal of International Financial Markets, Institutions and Money, 51, 92-105. doi:10.1016/j.intfin.2017.08.008

Burgstahler, D., \& Dichev, I. (1997). Earnings management to avoid earnings decreases and losses. Journal of Accounting and Economics, 24(1), 99-126. doi: 10.1016/S0165-4101(97)00017-7

De Long, J. B., Shleifer, A., Summers, L. H., \& Waldmann, R. J. (1990). Noise trader risk in financial markets. Journal of Political Economy, 98(4), 703-738. doi:10.1086/261703

DeAngelo, H., DeAngelo, L., \& Skinner, D. J. (1994). Accounting choice in troubled companies. Journal of Accounting and Economics, 17(1-2), 113-143. doi:10.1016/0165-4101(94)90007-8

Dechow, P. M. (1994). Accounting earnings and cash flows as measures of firm performance: The role of accounting accruals. Journal of Accounting and Economics, 18, 3-42. doi:10.1016/0165-4101(94)90016-7

Dechow, P. M., Ge, W., \& Schrand, C. (2010). Understanding earnings quality: A review of the proxies, their determinants and their consequences. Journal of Accounting and Economics, 50(2-3), 344-401. doi:10.1016/j. jacceco.2010.09.001

Dechow, P. M., Hutton, A. P., Kim, J. H., \& Sloan, R. G. (2012). Detecting earnings management: A new approach. Journal of Accounting Research, 50(2), 275-334. doi:10.1111/j.1475-679X.2012.00449.x

Dechow, P. M., \& Sloan, R. G. (1991). Executive incentives and the horizon problem: An empirical investigation. Journal of Accounting and Economics, 14(1), 51-89. doi:10.1016/0167-7187(91)90058-S

Dechow, P. M., Sloan, R. G., \& Sweeney, A. P. (1995). Detecting earnings management. The Accounting Review, 70(2), 193-225. Retrieved from http://www.jstor.org/stable/248303 
Dechow, P. M., Sloan, R. G., \& Sweeney, A. P. (1996). Causes and consequences of earnings manipulation: An analysis of firms subject to enforcement actions by the SEC. Contemporary Accounting Research, 13(1), 1-36. doi:10. 1111/j.1911-3846.1996.tb00489.x

Demirakos, E. G., Strong, N. C., \& Walker, M. (2010). Does valuation model choice affect target price accuracy? European Accounting Review, 19(1), 35-72. doi:10.1080/09638180902990630

Dichev, I. D., \& Skinner, D. J. (2002). Large-sample evidence on the debt covenant hypothesis. Journal of Accounting Research, 40(4), 1091-1123. doi:10.1111/1475-679X.00083

Fields, T. D., Lys, T. Z., \& Vincent, L. (2001). Empirical research on accounting choice. Journal of Accounting and Economics, 31(1-3), 255-307. doi:10.1016/S0165-4101(01)00028-3

Graham, J. R., Harvey, C. R., \& Rajgopal, S. (2005). The economic implications of corporate financial reporting. Journal of Accounting and Economics, 40(1-3), 3-73. doi:10.1016/j.jacceco.2005.01.002

Greene, W. H. (2012). Econometric Analysis (7 ed.). London (UK): Pearson.

Gu, Z., Lee, C.-W. J., \& Rosett, J. G. (2005). What determines the variability of accounting accruals? Review of Quantitative Finance and Accounting, 24(3), 313-334. doi:10.1007/s11156-005-6869-1

Healy, P. M., \& Wahlen, J. M. (1999). A review of the earnings management literature and its implications for standard setting. Accounting Horizons, 13 (4), 365-383. doi:10.2308/acch.1999.13.4.365

Hope, O. (2003). Disclosure practices, enforcement of accounting standards, and analysts' forecast accuracy: An international study. Journal of Accounting Research, 41 (2), 235-272. doi:10.1111/1475-679X.00102

Hribar, P., \& McInnis, J. (2012). Investor Sentiment and Analysts': Earnings forecast errors. Management Science, 58(2), 293-307. doi:10.1287/mnsc. 1110.1356

Huang, K., Lao, B., \& McPhee, G. (2017). Does stock liquidity affect accrualbased earnings management? Journal of Business Finance \& Accounting, 44(3-4), 417-447. doi:10.1111/jbfa.12236

Jensen, M. C., \& Meckling, W. H. (1976). Theory of the firm: Managerial behavior, agency costs and ownership structure. Journal of Financial Economics, 3(4), 305-360. doi:10.1016/0304-405X(76)90026-X

Jones, J. J. (1991). Earnings management during import relief investigations. Journal of Accounting Research, 29(2), 193-228. doi:10.2307/2491047 
Kang, S.-H., \& Sivaramakrishnan, K. (1995). Issues in testing earnings management and an instrumental variable approach. Journal of Accounting Research, 33(2), 353-367. doi:10.2307/2491492

Kent, R., \& Routledge, J. (2017). Use of benchmarks in predicting earnings management? Accounting \& Finance, 57(1), 239-260. doi:10.1111/acfi. 12130

Lee, C., Shleifer, A., \& Thaler, R. H. (1991). Investor sentiment and the closed end fund puzzle. The Journal of Finance, 46 (1), 75-109. doi:10.2307/ 2328690

Martinez, A. L. (2011). The role of analysts as gatekeepers: enhancing transparency and curbing earnings management in Brazil. Revista de Administração Contemporânea, 15(4), 712-730. doi:10.1590/S1415-65552011 000400009

Mota, R. H. G., Silva Filho, A. C. da C., Oliveira, A. F., \& Paulo, E. (2017). Previsão de lucro e gerenciamento de resultados: Evidências empíricas no mercado acionário brasileiro. Revista Universo Contábil, 13(1), 6-26. doi:10. 4270/ruc.2017101

Nardi, P. C. C., \& Nakao, S. H. (2009). Gerenciamento de resultados e a relação com o custo da dívida das empresas brasileiras abertas. Revista Contabilidade E Finanças, 20(50), 77-100. Retrieved from http://www.redalyc. org/articulo.oa? id $=257119520005$

Pae, J. (2005). Expected accrual models: the impact of operating cash flows and reversals of accruals. Review of Quantitative Finance and Accounting, 24(1), 5-22. doi:10.1007/s11156-005-5324-7

Polk, C., \& Sapienza, P. (2009). The stock market and corporate investment: A test of catering theory. The Review of Financial Studies, 22(1), 187-217. doi:10.1093/rfs/hhn030

Rezende, G. P., \& Nakao, S. H. (2012). Gerenciamento de resultados e a relação com o lucro tributável das empresas brasileiras de capital aberto. Revista Universo Contábil, 8(1), 6-21. doi:10.4270/ruc.2012101

Riahi-Belkaoui, A. (1999). Earnings measurement, determination, management, and usefulness: An empirical approach. London (UK): Quorum Books.

Sayed, S. A. (2017). How much does valuation model choice matter? Target price accuracy of PE and DCF model in Asian emerging markets. Journal of Accounting in Emerging Economies, 7(1), 90-107. doi:10.1108/JAEE-102014-0055 
Shleifer, A., \& Vishny, R. W. (1997). The limits of arbitrage. The Journal of Finance, 52(1), 35-55. doi:10.1111/j.1540-6261.1997.tb03807.x

Silva, A. F., Weffort, E. F. J., Flores, E. da S., \& Silva, G. P. (2014). Earnings management and economic crises in the Brazilian capital market. Revista de Administração de Empresas, 54(3), 268-283. doi:10.1590/S0034-7590201 40303

Simpson, A. (2013). Does investor sentiment affect earnings management? Journal of Business Finance \& Accounting, 40(7-8), 869-900. doi:10.1111/ jbfa. 12038

Sincerre, B. P., Sampaio, J. O., Famá, R., \& Santos, J. O. (2016). Emissão de dívida e gerenciamento de resultados. Revista Contabilidade \& Finanças, 27(72), 291-305. doi:10.1590/1808-057x201601660

Sloan, R. G. (1996). Do stock prices fully reflect information in accruals and cash flows about future earnings? The Accounting Review, 71 (3), 289-315. Retrieved from http://www.jstor.org/stable/248290

Stein, J. C. (1996). Rational capital budgeting in an irrational world. The Journal of Business, 69(4), 429-455. doi:10.1086/209699

Xavier, G. C., \& Machado, M. A. V. (2017). Anomalies and investor sentiment: Empirical evidences in the brazilian market. Brazilian Administration Review, 14(3), 1-25. doi:10.1590/1807-7692bar2017170028

Yoshinaga, C. E., \& Castro Junior, F. H. F. de. (2012). The relationship between market sentiment index and stock rates of return: A panel data analysis. Brazilian Administration Review, 9(2), 189-210. doi:10.1590/S18 07-76922012000200005

\section{AUTHOR NOTE}

Kléber F. Miranda, Universidade Federal do Ceará (UFC); Márcio A. V. Machado, Universidade de Brasília (UnB); Luciana A. F. Macedo, Universidade Federal da Paraíba (UFPB).

Kléber F. Miranda is now Professor at Universidade Federal Rural do Semi-Árido (Ufersa). Márcio A. V. Machado is now Professor at Universidade Federal da Paraíba (UFPB). Luciana A. F. Macedo is now Professor at União de Ensino Superior de Campina Grande (Unesc).

Correspondence concerning this paper should be addressed to Kléber F. Miranda, Avenida Francisco Mota, 572, Costa e Silva, Mossoró, Rio Grande do Norte, Brazil, CEP 59.625-900.

E-mail:mirandakf@ufersa.edu.br 
Investor sentiment and earnings management: Does analysts' monitoring matter?

\section{EDITORIAL BOARD}

Editor-in-chief

Silvio Popadiuk

Associated Editor

Paulo Ceretta

Technical Support

Vitória Batista Santos Silva

\section{EDITORIAL PRODUCTION}

Publishing Coordination

Irina Migliari

Language Editor

Daniel Leão

Editorial Trainee

Maria Luiza Vanz

Layout Designer

Emap

Copyeditor

Irina Migliari
Graphic Designer

Libro 